\title{
HUBUNGAN ANTARA MINAT BACA DAN KEAKTIFAN BELAJAR DENGAN HASIL BELAJAR ILMU PENGETAHUAN ALAM PADA SISWA KELAS VII SMP NEGERI 53 BATAM
}

\section{THE RELATIONSHIP BETWEEN READING INTEREST AND LEARNING ACTIVITINESS AND SCIENCE SUBJECT LEARNING OUTCOMES AT GRADE VII STUDENTS OF SMP NEGERI 53 BATAM,}

\author{
Septi Riani ${ }^{1}$, Nurhaty Purnama Sari ${ }^{2 *}$, Fauziah Syamsi $^{3}$ \\ ${ }^{123}$ Program Studi Pendidikan Biologi, FKIP, Universitas Riau Kepulauan, Batam \\ *Korespondensi : nurhatypurnamasari@gmail.com
}

\begin{abstract}
Abstrak
Penelitian ini bertujuan untuk mengetahui hubungan antara minat baca (X1) dan keaktifan belajar (X2) dengan hasil belajar (Y) IPA siswa kelas VII SMP Negeri 53 Batam. Penelitian ini merupakan penelitian kuantitatif dengan menggunakan pendekatan korelasi sederhana dan analisis korelasi berganda. Berdasarkan analisis data diperoleh nilai korelasi cukup positif antara minat baca dengan hasil belajar dengan nilai korelasi $(\mathrm{r})=0,573(57,3 \%)$ sehingga hipotesis $\mathrm{H}_{\mathrm{a}}$ diterima dan $\mathrm{H}_{\mathrm{o}}$ ditolak, sedangkan koefisien determinasi $\left(\mathrm{R}^{2}\right)=0,329$ bahwa pengaruh minat baca belajar dalam hasil belajar sebesar 32,9\%. Hubungan antara keaktifan belajar dengan hasil belajar, nilai korelasi $(r)=0,496(49,6 \%)$ sehingga hipotesis $\mathrm{H}_{\mathrm{a}}$ diterima dan $\mathrm{H}_{\mathrm{o}}$ ditolak, sedangkan koefisien determinasi $\left(\mathrm{R}^{2}\right)=0,246$ bahwa pengaruh keaktifan belajar dalam hasil belajar sebesar 24,6\%. Sedangkan hubungan antara minat belajar dan keaktifan belajar dengan hasil belajar nilai korelasi $(r)=0,628(62,8 \%)$ sehingga hipotesis $H_{a}$ diterima dan $H_{o}$ ditolak, sedangkan koefisien determinasi $\left(\mathrm{R}^{2}\right)=0,395$ bahwa pengaruh minat belajar dan keaktifan belajar dalam hasil belajar sebesar $39,5 \%$.
\end{abstract}

Kata Kunci: Minat belajar, Keaktifan belajar, Hasil belajar, Korelasi

\begin{abstract}
This study aims to determine the relationship between reading interest (X1) and learning activeness (X2) and science subject learning outcomes (Y) grade VII students of SMP Negeri 53 Batam. This research was quantitative approach using simple correlation and multiple correlation analysis. Based on data analysis obtained quite positive correlation values between reading interest and learning outcomes with correlation value $(r)=0.573(57.3 \%)$, so $H_{a}$ hypothesis was accepted and $H_{o}$ was rejected, meanwhile the coefficient of determination $(R 2)=0.329$ that influence learning reading interest in learning outcomes 32.9\%. The relationship between the learning activeness and learning outcomes, the correlation value $(r)=$ 0.496 (49.6\%), so the hypothesis $H_{a}$ was accepted and $H_{o}$ was rejected, meanwhile the coefficient of determination $(R 2)=0.246$ so that learning activeness influence toword learning results by $24.6 \%$. Meanwhile the relationship between learning interest and activeness and learning outcomes at correlation value $(r)=0.628(62.8 \%)$, so the hypothesis $H_{a}$ was accepted and $H_{o}$ was rejected, meanwhile the coefficient of determination $\left(R^{2}\right)=0.395$ influenced learning interest and learning activeness toward learning outcomes at $39,5 \%$.
\end{abstract}

Keywords: learning Interest, learning Activeness, learning outcome, Correlation

\section{PENDAHULUAN}

Minat baca merupakan keinginan seseorang untuk mengetahui sesuatu yang ada dalam sebuah buku bacaan sebagai informasi yang dibutuhkan dalam pengetahuannya. 
Siswa yang gemar membaca akan memperoleh pengetahuan dan wawasan yang baru sehingga mampu meningkatkan kecerdasannya dan mereka lebih mampu menjawab tantangan hidup pada masa mendatang. Selain itu, keaktifan belajar merupakan suatu upaya pembaruan pendidikan dan pembelajaran. Keterlibatan siswa dalam proses pembelajaran merupakan suatu pelaksanaan dari keaktifan siswa. Menurut Cahyandaru (2013) keaktifan merupakan suatu kegiatan atau aktivitas yang dilakukan baik secara fisik maupun non fisik seperti mental, intelektual, dan emosional.

Dalam proses pembelajaran tentu saja disamping menerima materi pelajaran dari guru, siswa dapat berperan aktif dengan cara melakukan aktivitas yang dapat mendukung proses belajar, diantaranya dengan cara berdiskusi, membaca dan memahami materi pelajaran, melaksanakan tugas yang di perintahkan guru atau mencari sumber materi lain yang sekiranya dapat membantu mereka dalam memahami materi pembelajaran untuk mendapatkan hasil belajar yang lebih baik. Menurut Susanto (2013) Hasil belajar adalah perubahan yang terjadi pada diri siswa, baik yang menyangkut asfek kognitif, afektif, dan psikomotorik. Adapun hasil belajar yang diperoleh siswa di sekolah, pada dasarnya merupakan hasil nyata dari sebuah proses pendidikan. Dalam keseluruhan proses pendidikan di sekolah kegiatan belajar merupakan kegiatan yang paling pokok, diantaranya dengan mengembangkan minat baca dan keaktifan siswa dalam belajar.

Hasil observasi penulis di SMP Negeri 53 Batam, kegiatan membaca buku sudah jarang dilakukan terutama buku yang berhubungan dengan proses pembelajaran. Hal ini terjadi akibat kurangnya minat baca siswa akan buku pelajaran. Ini terbukti ketika guru berhalangan masuk mengajar mereka lebih memilih bermain dari pada membaca buku. Berdasarkan masalah yang telah dipaparkan di atas, peneliti menduga bahwa minat baca dan keaktifan belajar mempunyai hubungan dengan hasil belajar siswa. Oleh karena itu, peneliti sangat tertarik untuk mengadakan penelitian yang berjudul "Hubungan Antara Minat Baca dan Keaktifan Belajar dengan Hasil Belajar IPA pada Siswa Kelas VII SMP Negeri 53 “

\section{METODOLOGI}

Penelitian ini adalah penelitian kuantitatif dengan menggunakan pendekatan penelitian korelasi. Penelitian ini diarahkan untuk menguji hubungan antara variabel bebas, yaitu minat baca $\left(\mathrm{X}_{1}\right)$ dan keaktifan belajar siswa $\left(\mathrm{X}_{2}\right)$ dengan variabel terikat, yaitu 
hasil belajar IPA (Y). Populasi dalam penelitian ini adalah seluruh siswa kelas VII SMP Negeri 53 Batam yang berjumlah 181 siswa. Adapun penentuan jumlah sampel penelitian ini menggunakan teknik random sampling. Dari penarikan sampel secara acak yang dilakukan melalui undian dengan berdasarkan perhitungan rumus solvin, maka sampel penelitian diperoleh 125 lemudian digenapkan menjadi 4 kelas berjumlah 136 siswa. Instrumen yang digunakan dalam penelitian ini berupa dokumentasi dan angket. Dokumen yang saya ambil berupa nilai hasil belajar IPA dari Ujian Tengah Semester Genap. Sedangkan angket (kuesioner) yang digunakan untuk memperoleh data minat baca $\left(\mathrm{X}_{1}\right)$ dan keaktifan belajar $\left(\mathrm{X}_{2}\right)$ menggunakan skala likert dalam bentuk checklist. Uji coba instrument menggunakan uji validitas dan uji reabilitas. Uji validitas yang di gunakan pada penelitian ini yaitu validitas internal. Untuk mengetahui reabilitas suatu instrumen maka digunakan uji reabilitas Internal Consistency, dengan rumus alpha-crobach.

\section{PEMBAHASAN}

Data variabel minat baca yang diberikan kepada sampel sebanyak 136 siswa dengan instrument yang terdiri dari 25 pernyataan, diperoleh harga mean $\left(\sum \mathrm{X}\right)$ sebesar 79,48, median (Me) sebesar 79 dan modus (Mo) sebesar 83. Untuk klasifikasi minat baca siswa yang diperoleh berkategori baik sebanyak 23 siswa (16.91\%), kategori cukup baik sebanyak 65 siswa (47,79\%), kategori kurang baik sebanyak 44siswa (32.35\%) dan kategori sangat kurang baik sebanyak 4siswa (2.94\%).

Selanjutnya data variabel keaktifan belajar yang diberikan kepada sampel sebanyak 136 siswa dengan instrument yang terdiri dari 25 pernyataan, diperoleh harga mean $\left(\sum \mathrm{X}\right)$ sebesar 85.67, median (Me) sebesar 88dan modus (Mo) sebesar 94. Klasifikasi Keaktifan Belajar dari 136 siswa diketahui sebanyak 54 orang (39.71\%) memiliki keaktifan belajar baik, sebanyak 53 siswa (38.97\%) memiliki keaktifan belajar cukup baik, sebanyak 24 orang (17.65\%) memiliki keaktifan belajar tidak baik, dan sebanyak 4 orang (3.68\%) memiliki minat baca sangat tidak baik. Sedangkan data variabel hasil belajar siswa diperoleh dari rentang nilai IPA siswa. Rentang nilai terendah 44 sampai nilai tertinggi 100. Berdasarkan distribusi nilai tersebut diperoleh nilai rata-rata 76,01 dan nilai tengah 76. Nilai yang sering muncul 84, nilai simpangan baku13.03, dan rentang 56. Serta Frekuensi hasil belajar siswa terbanyak berada pada interval 79-85 dengan jumlah 34 
(25.00\%), sedangkan frekuensi paling sedikit berada pada kelas interval 93-99 dengan jumlah $3(2.21 \%)$.

Selanjutnya berdasarkan hasil analisis data diketahui bahwa minat baca siswa SMP Negeri 53 Batam tergolong cukup baik. Sedangkan minat baca dengan hasil belajar IPA memiliki hubungan yang cukup kuat dan positif. Hal ini dibuktikan dari hasil penelitian berdasarkan analisis korelasi Product Moment diperoleh nilai $\mathrm{rx}_{1} \mathrm{y}$ sebesar 0,573, dengan tingkat signifikan 0.000 . Nilai ini lebih kecil dari 0.05 atau $\operatorname{sig}<\alpha$, maka Ha diterima dan Ho ditolak. Ini berarti minat baca memiliki hubungan yang signifikan dan positif dengan hasil belajar. Hasil koefisien determinasi yang diperoleh sebesar 0,329 menunjukan 32,9\% perubahan pada hasil belajar dapat dijelaskan oleh minat baca. Dalam katagori keaktifan belajar siswa SMP Negeri 53 Batam juga tergolong cukup baik. Sedangkan hubungan keaktifan belajar dengan hasil belajar IPA pada siswa kelas VII SMP Negeri 53 Batam juga memiliki hubungan yang cukup kuat. Ini terbukti dari hasil analisis korelasi Product Moment diperoleh nilai $\mathrm{rx}_{2} \mathrm{y}$ sebesar 0,496, dengan tingkat signifikan 0.000. Nilai ini lebih kecil dari 0.05 atau sig $<\alpha$, maka Ha diterima dan Ho ditolak. Ini berarti keaktifan belajar memiliki hubungan yang signifikan dan positif dengan hasil belajar. Hasil koefisien determinasi yang diperoleh sebesar 0,246 menunjukan 24,6\% perubahan pada hasil belajar dapat dijelaskan oleh keaktifan.

Hasil analisis korelasi ganda menunjukan bahwa minat baca dan keaktifan belajar dengan hasil belajar siswa kelas VII SMP Negeri 53 Batam memiliki hubungan yang kuat. Hal ini terlihat dari nilai korelasinya sebesar 0,629 dengan tingkat signifikan 0.000. Nilai ini lebih kecil dari 0.05 atau sig $<\alpha$, ini berarti minat baca dan keaktifan belajar mimiliki hubungan yang signifikan dengan hasil belajar. Adapun F hitung minat baca dan keaktifan belajar memiliki nilai 43.422 sedangkan $F$ tabel memiliki nilai 3.07. Ini berarti $F$ hitung (43.422) > F tabel (3.07), sehingga hipotesis penelitian diterima. Koefisien determinasi sebesar 0,395. Ini berarti persentase sumbangan variabel minat baca $\left(X_{1}\right)$ dan $\left(X_{2}\right)$ dalam model regresi sebesar 39,5\% sedangkan sisanya sebanyak 60,5\% dijelaskan oleh variabel lain yang tidak dimasukkan dalam model regresi.

\section{KESIMPULAN}

Terdapat hubungan yang signifikan dan positif minat baca dengan hasil belajar IPA siswa kelas VII SMP Negeri 53 Batam. Hal ini ditunjukan pada hasil perhitungan dimana r 
hitung (0.573) $>\mathrm{r}$ tabel (0.142) dan sig. (0.000) $<\alpha(0.05)$; Terdapat hubungan yang signifikan dan positif keaktifan belajar dengan hasil belajar IPA siswa kelas VII SMP Negeri 53 Batam. Hal ini ditunjukan pada hasil perhitungan dimana $r$ hitung $(0.492)>r$ tabel (0.142) dan sig. (0.000) < $<(0.05)$ serta terdapat hubungan yang signifikan dan positif antara minat baca dan keaktifan belajar siswa dengan hasil belajar IPA siswa kelas VII SMP Negeri 53 Batam. Hal ini ditunjukan pada hasil perhitungan dimana $r$ hitung $(0.629)>\mathrm{r}$ tabel $(0.142)$ dan sig. $(0.000)<\alpha(0.05)$.

\section{REFERENSI}

Arikunto. 2013. Prosedur Penelitian. Jakarta: Rineka Cipta.

Daryanto. 2013. Inovasi Pembelajaran Efektif. Bandung: Yrama widya.

Harjanto, B. 2011. Merangsang \& Melejitkan Minat Baca Anak. Yogyakarta: Manika Books.

Rahayu. 2009. Faktor-Faktor Yang Mempengaruhi Minat Baca Siswi Madeasah Aliyah Wahid Hasyim Yogyakarta Yang Menetap Di Asmara. (Skripsi). Yogyakarta: Universitas Islam Negeri Sunan Kali Jaga.

Rianthi. 2010. Peningkatan Minat Baca Anak Melalui Mendongeng: Studi Kasus di Perpustakaan Pustaka Kelana Rawamangun. (Skripsi). Jakarta:Universitas Indonesia.

Sari, I P. 2013. Hubungan Minat Baca Dengan Prestasi Belajar Pada Mata Pelajaran IPS Geografi. Universitas Negeri Gorontalo.

Suherman, A. 2011. Pengaruh Pendekatan Pembelajaran dan Minat Baca Terhadap Pemahaman Puisi. Pendidikan Bahasa dan Sastra. 1: 68-87. 